\title{
PENINGKATAN MINAT GURU PADA PERENCANAAN PENELITIAN TINDAKAN KELAS BERKARAKTER PEMBELAJARAN ABAD-21
}

\author{
Waluyo ${ }^{1}$, Sukatiman ${ }^{1}$ \\ ${ }^{1}$ Universitas Sebelas Maret, Surakarta \\ *Corresponding email: waluyoptb@staff.uns.ac.id
}

Naskah diterima: 2 Agustus 2021| Disetujui: 1 September 2021 | Diterbitkan: 2 September 2021

\begin{abstract}
The State Vocational High School (SMK N I) Jenar of central Java holds $20 \%$ engineering science teachers, and more than 30\% of young teachers still have not received Teacher Profesional Education training. The condition became a problem of the success of the development of education, so a Class Action Research (CAR) workshop is required. This research aims to provide a deepening of 21st-century learning characteristics to improve learning in accordance with the field of education it pursues. The implementation method is carried out by providing a deepening of the material characteristics of 21st-century learning, the theory of Class Action Research (CAR), and following with the guiding teachers in planning CAR proposals. The results showed that teachers are able to plan Class Action Research with the concept of 21st-century learning. There are 5 teachers who plan research in the realm of learning models, 2 teachers interested in doing PTK in the field of methods, 2 teachers planning class action research in improving the media, and 2 teachers interested in doing action research in the field of attitude and motivation. The researcher still tutoring through email so that the planned class action research is conducted by the teachers.
\end{abstract}

Keywords: TPaCK ; Century-21th competence; CAR proposal.

Abstrak: Sekolah Mengah Kejuruan Negeri (SMK N I) Jenar Sragen Jawa Tengah memiliki guru kurang lebih 20\% dengan latar belakang ilmu murni, lebih dari 30\% guru muda belum memperoleh pelatihan Pendidikan Profesi Guru (PPG). Kondisi para guru menjadi permasalahan keberhasilan perkembangan pendidikan pada SMK tersebut, sehingga diperlukan workshop Penelitian Tindakan Kelas (PTK). Penelitian ini bertujuan memberi pendalaman pengetahuan tentang pembelajaran abad21 sebagai dasar guru untuk merencanakan PTK, sehingga dapat meningkatkan pembelajaran sesuai bidang pendidikan yang digelutinya. Metode pelaksanaan dilakukan dengan memberikan pendalaman materi karakteristik pembelajaran abad-21, teori PTK, dan melakukan bimbingan kepada guru dalam perencanaan proposal PTK. Hasil penelitain menunjukkan bahwa guru mampu merencanakan Penelitian Tindakan Kelas (PTK) dengan konsep pembelajaran abad-21. Terdapat lima guru yang merencanakan penelitian dalam ranah model pembelajaran, dua guru berminat melakukan PTK dalam bidang metode, dua guru merencanakan penelitian tindakan kelas dalam meningkatkan media, dan dua guru berminat melakukan penelitian tindakan dalam bidang sikap dan motivasi. Penelitian lanjutan tetap dilakukan melalui komunikasi online agar penelitian tindakan kelas yang sudah direncanakan benar-benar dapat dilaksanakan oleh guru.

Kata kunci: Pelatihan PTK, Kompetensi pedagogik, Hasil belajar meningkat. 


\section{PENDAHULUAN}

Guru memiliki tugas dan kewajiban pokok mengajar, dengan beban mengajar yang cukup padat pada setiap harinya. Namun kewajiban rutin saja tidak cukup bagi seorang guru, karena masih dituntut untuk membuat evaluasi dan refleksi terhadap pembelajaran yang sudah dilakukannya,hal tersebut guna mendapatkan perbaikan prestasi peserta didik dari tahun ke tahun.

Seorang guru dituntut untuk selalu meningkatkan kompetensi yang meliputi kompetensi profesional, pedagogik, kepribadian, dan sosial. Kompetensi tersebut tercantum dalam kurikulum 2013 yang menegaskan dalam metode penyampaian materi harus mencerminkan proses pembelajaran yang mengandung unsur $4 \mathrm{C}$, yaitu berpikir kritis dan memecahkan masalah, berpikir kreatif dan inovatif, bekerjasama, dan kemampuan komunikasi. Kurikulum K-13 juga menekankan budaya pembelajaran dengan menerapkan keterampilan berpikir tingkat tinggi (HOTS). Pembelajaran kepada siswa dapat dianggap sebagai pembelajaran bagi orang dewasa/remaja sehingga konsep pembelajarannya juga harus menggunakan teknologi update yang dapat menyesuaikan dengan kecepatan perkembangan zaman, sehingga ilmu yang didapat siswa tidak cepat usang. Munculnya perkembangan komunikasi berbasis gadget merubah kebiasaan cara mendapatkan ilmu di sekolah, dari mencatat dan membaca secara manual menjadi browsing dan mengolah data digital. Hal ini akan menjadi masalah apabila para guru tidak mengembangkan profesionalitasnya sesuai dengan kemajuan zaman. Berikut merupakan beberapa pengalaman yang dihadapi guru.

a. Belum teridentifikasi dengan jelas model pembelajaran yang membuat siswa aktif mencari tahu melalui pengalaman belajar.

b. Penerapan pembelajaran yang belum mengedepankan Higher Ordered Thinking (HOTS),baik dalam perencanaan pembelajaran, proses pembelajaran, dan evaluasi pembelajaran sehingga siswa cenderung pasif dalam PBM.

c. Pembelajaran yang belum efektif menyebabkan kompetensi yang didapat siswa belum lengkap untuk diterapkan pada DUDIKA, sehingga pengangguran SMK masih cukup tinggi.

Untuk dapat memenuhi kriteria tersebut, salah satu metode dalam meningkatkan kompetensi pengajar yaitu melalui penguasaan Tecnhnological Pedagocical Content Knowledge (TPACK), (Koehler et al., 2017).

\section{Meningkatkan Kompetensi Guru dalam Bidang TPACK}

Technological Pedagogical Content Knowledge (TPACK) adalah konsep mengajar yang menekankan penguasaan kompetensi terintegrasi dari seorang guru yang meliputi teknologi, ilmu 
pedagogi, dan penguasaan isi materi. Hal tersebut agar dapat melaksanakan proses belajar mengajar secara efektif (The TPACK framework and its knowledge components., 2012).

Beberapa macam cara dapat dilakukan untuk mengembangkan profesionalitas guru,

a. Mengembangkan metode pembelajaran, kurikulum, dan mengembangkan pendidikan secara umum.

b. Menjaga keterbaharuan ilmu melalui informasi dan pengalaman dari luar sebagai bagian dari kemajuan profesionalitas diri.

c. Melakukan pembelajaran melalui kegiatan lapangan secara nyata sehingga siswa lebih memahami materi. Dengan demikian akan merubah pandangan lama dari siswa menerima menjadi siswa mencari.

d. Melakukan refleksi pribadi, di mana profesionalitas dikreasikan untuk mendapatkan pengalaman baru. (McLeod \& Richardson, 2014).

TPACK dianggap sebagai bagian penting dalam program persiapan guru untuk menghasilkan masa depan. Guru yang kompeten dalam penggunaan ICT dalam mengajar, menguasai konsep sains dan dapat menerapkan yang terbaik mengajarkan strategi selama pembelajaran (Bunyamin \& Phang, 2012).

Sistem kerja guru terhadap kemampuan integrasi teknologi, pedagogi, dan isi materi (TPACK) dapat internalisasikan pada gambar 1 berikut.

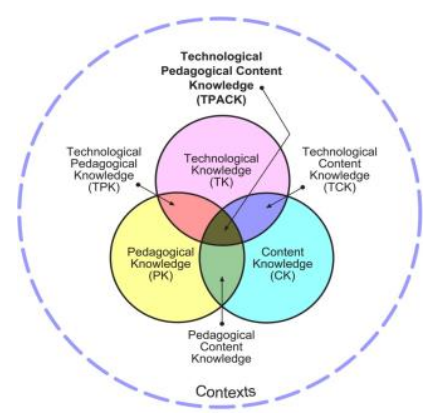

Gambar 1. The TPACK Framework and its Knowledge Components.

Berdasarkan peraturan perundangan dan teori-teori di atas, maka pemahaman guru pada ketiga ranah (teknologi, pedagogi dan pengetahuan profesinya) harus ditingkatkan melalui pendalaman teori-teori yang mendukung karakter pembelajaran abad-21 dan pemahaman tentang Penelitian Tindakan Kelas (PTK) yang dipaparkan di bawah ini. 


\section{Teori Belajar Konstruktivistik}

Konstruktivisme didefinisikan sebagai pembelajaran yang bersifat dapat dipelajari secara umum, yaitu tindakan menciptakan makna terhadap sesuatu yang dipelajari saat ini berdasarkan pengalaman yang dikonstruk sebelumnya (Mok, 1993). Konstruktivisme bukan merupakan gagasan yang baru, setelah situasi dunia nyata disajikan, pengalaman dan pengetahuan sebelumnya dari pembelajar tertanam dalam desain kegiatannya (Hung \& Nichani, 2001). Pengetahuan tidak mudah ditransfer dari guru kepada siswa, karena setiap individu memiliki skema sendiri terhadap apa yang diketahuinya. Dalam menyelesaikan permasalahan yang ada di kelas, guru harus aktif untuk merencana secara bersama, dan meningkatkan tujuan pembelajaran secara nyata melalui observasi dan refleksi (Shanmugam \& Shok Me, 2017).

Konstruksi pengetahuan merupakan suatu proses kognitif asimilasi dan akomodasi untuk mencapai suatu keseimbangan sehingga menjadi suatu skema (jamak: skemata) yang baru. Beberapa jenis aliran kontruktivistik yang menjadi penelitian utama di Korea adalah Project based learning (PrBL), Inquiry Based learning dan Problem Based Learning.

Sejalan dengan teori konstruktivistik yang sudah dipaparkan di atas, dalam bidang vokasi memiliki karakter sendiri dalam implementasi pembelajaran konstruktivistik. (Kultusminister Konferenz, 2002) menyatakan bahwa pendidikan dan pelatihan kejuruan mensyaratkan pembelajaran siswa menekankan pada tugas-tugas yang memiliki orientasi tindakan dan para siswa diberikan kesempatan secara mandiri untuk merencanakan, melakukan, dan menilai tugas-tugas kerja dalam konteks aktivitas profesionalnya.

\section{Berpikir Tingkat Tinggi (HOTS)}

Keterampilan berpikir tingkat tinggi yang merupakan arti serapan dari dari Higher Order Thinking Skills (HOTS) adalah suatu kegiatan berpikir yang melibatkan tingkat kognitif hirarki tinggi dari taksonomi berpikir Bloom. HOTS mengalami kemajuan pesat pada pembelajaran abad-21. Hal tersebut dikarenakan tujuan pembelajaran dengan keterampilan berpikir tingkat tinggi (HOTS) akan menyiapkan siswa untuk sukses pada dunia nyata yang penuh tantangan saat ini (Yeung, 2015).

Kemampuan berpikir tingkat tinggi juga membekali siswa dengan kemampuan menyampaikan ide gagasan yang mempunyai makna, dapat di nalar, dan percaya diri, baik secara lisan, tertulis, maupun tindakan. Kata kunci pertanyaan untuk melatih berpikir tingkat tingi antara lain, mengapa? bagaimana caranya? berikan alasan! dengan cara apa? harus bertindak bagaimana? seandainya? dan lain-lain. Kata kunci dari keberhasilan HOTS adalah perencanaan. Tanpa ada perencanaan yang teliti, 
maka siswa akan lebih sering menggunakan pertanyaan mengingat kembali daripada pertanyaan berpikir tingkat tinggi (Jeffrey et al., 2014).

Pada sekolah-sekolah vokasi, selama ini pembelajaran praktek lebih menekankan pada prosedur, penerapan sederhana, dan analisis sederhana yang termasuk dalam kategori kemampuan berpikir tingkat rendah (LOTS) yang hanya dapat menjawab pertanyaan yang jawabannya dapat ditemukan langsung dari sumber yang dihadapi. Contoh pertanyaan LOTS meliputi pertanyaan, siapa? kapan? dan dimana?. Kemampuan berpikir tingkat rendah merupakan perantara (scaffolding) untuk memperoleh kemampuan berpikir yang lebih tinggi. Pemikiran tingkat rendah seperti membedakan, penerapan sederhana, analisis sederhana, dan pengetahuan sebelumnya seperti pengetahuan prosedural dan bentuk penalaran merupakan faktor penting dalam scaffolding.

\section{Model Problem Based Learning (PBL)}

Sejak awal 1960-an terdapat perdebatan yang sedang berlangsung dalam ilmu pendidikan tentang bagaimana mempromosikan pembelajaran aktif pada siswa. Publikasi musim semi Bruner pada tahun 1961 dengan judul 'The Act of Discovery' dapat dilihat sebagai awal dari debat tersebut. Bruner menentang gaya pengajaran ekspositori yang dominan pada saat itu dan berargumentasi sebagai pengganti pemecahan masalah sebagai dasar untuk belajar dan mengajar. Maka sejak saat itu banyak penelitian dilakukan oleh para ahli dan pembelajaran jenis discovery dan problem based learning menjadi fokus dalam proses pembelajaran di kelas .

Model Pembelajaran berbasis masalah adalah konsep proses belajar mengajar yang membantu pengajar untuk mengkondisikan lingkungan pembelajaran yang diawali dengan masalah yang tidak terstruktur dan memungkinkan siswa mendapatkan pengalaman belajar yang lebih nyata. Pendekatan pembelajaran problem based lebih mengutamakan proses penyelesaian masalah dibandingkan hasil akhir (Polya, 1957). Pada proses pembelajaran, harus mengupayakan adanya proses berpikir yang melibatkan pengalaman nyata bagi siswa, berpikir kritis, dan pembelajaran secara aktif. Oleh karenanya, diupayakan proses belajar yang memungkinkan siswa dapat memiliki keterampilan menyelesaikan masalah $(P B L)$.

Pembelajaran berbasis masalah dimulai dengan melakukan kerja kelompok antar peserta didik. Peserta didik menyelidiki sendiri, menemukan permasalahan, kemudian menyelesaikan masalahnya di bawah petunjuk fasilitator (pengajar). Motivasi siswa untuk aktif berpartisipasi dalam kelompok akan menimbulkan kepercayaan diri. Kepercayaan diri/kemanjuran diri dalam kelompok menunjuk pada kemampuanya untuk aktif dalam keberhasilan kelompok dalam memproses, membangun, mengemukakan ide, menyelesaikan konflik, dan koordinasi aktifitas kelompok (Hanham \& Cormick, 2016). 
Beberapa karakteristik PBL diantarannya, 1) pembelajaran berbasis pada siswa, 2) pembelajaran pada kelompok kecil, 3) pengajar berperan sebagai fasilitator, atau pembimbing, 4) permasalahan dihadirkan pada awal pembelajaran, 5) temuan masalah digunakan sebagai alat untuk mendapat pengetahuan yang diharapkan dan keterampilan problem solving yang dibutuhkan sehingga pada akhirnya dapat menjadi penyelesai masalah (problem solver) (Barrow, 1996). Terdapat satu penambahan yang penting untuk didapatkan yaitu informasi baru pembelajaran yang mengarah pada pembelajaran mandiri (Dochy, Segers, \& Bos, 2003). Pada buku klasiknya tentang bagaimana memecahkan masalahnya, (Polya, 1945) menawarkan 4 langkah sebagai berikut.

1. Pahami masalah. Siswa yang memiliki masalah harus melihat apa yang diberikan, apa yang tidak diketahuinya, dan cara apa yang dijinkan. Pendeknya siswa harus memahami masalah.

2. Menciptakan rencana. Siswa harus menentukan metode umum, seperti menyatakan ulang masalah sehingga masalah lebih sederhana.

3. Buat rencana. Siswa membuat perhitungan dan metode lain yang diperlukan.

4. Lihat kembali. Siswa harus mengamati proses berjalan, mencoba untuk melihat bagaimana pengalaman dapat membantu memecahkan masalah lain.

Pengembangan prinsip pembelajaran berbasis masalah sebagai diantarannya, 1) identifikasi permasalahan dilakukan melalui pendapat siswandari kasus yang diberikan oleh guru, 2) menetapkan masalah dengan cara menyeleksi informasi yang relevan dengan cara siswa diajak mencatat sejumlah fakta pendukung yang sesuai dengan masalah, 3) mengembangkan pemecahan masalah melalui identifikasi alternatif atau brain storming, 4) melakukan tindakan strategis terhadap apa yang sudah diselesaikan, 5) mengecek dan mengevaluasi pengaruh-pengaruh dari solusi yang dilakukan dengan menggunakan rujukan seperti rujukan Standar Nasional Indonesia (SNI) (Stein, 1984).

Berdasarkan pendapat para peneliti tersebut, maka langkah-langkah yang perlu diperhatikan dalam merancang program pembelajaran problem based learning agar proses pembelajaran benarbenar menjadi berpusat pada siswa (student-centered) diantarannya, 1) memfokuskan permasalahan (problem) sekitar pembelajaran konsep-konsep yang esensial dan strategis, 2) memberikan kesempatan kepada siswa untuk mengevaluasi gagasannya melalui eksperimen atau studi lapangan. Siswa akan menggali data-data yang diperlukan untuk memecahlkan masalah yang dihadapinya, 3) memberikan kesempatan kepada siswa untuk mengelola data yang mereka miliki, yang merupakan proses latihan metakognisi, 4) memberikan kesempatan kepada siswa untuk mempresentasikan solusi-solusi yang mereka kemukakan. 
Bagaimana memberikan permasalahan secara berjenjang pada kelas, (Wellesley R. Foshay, 2009) memberikan gambaran sebagai berikut.

Tabel 1. Bagaimana Membedakan Tingkat Masalah pada Kelas

\begin{tabular}{lll}
\hline \multicolumn{1}{c}{ Terstruktur dengan } & \multicolumn{1}{c}{ Terstruktur Menengah } & \multicolumn{1}{c}{ Tidak Terstruktur } \\
\hline Pernyataan awal jelas & Didefinisikan dengan jelas tentang & Tidak terjabarkan \\
& pengetahuannya & \\
Pernyataan tujuan & Didefinisikan dengan jelas & Tidak terdefinisi dengan baik \\
Langkah kerja & Didefinisikan dengan jelas & Dibuat tidak jelas \\
Rintangan-rintangan & Dijelaskan & Bisa diketahui atau tidak \\
& & dijelaskan \\
Contoh & Akses ke komputer & Tidak boleh ada produk baru jika \\
& & tidak ada rencana pemasaran
\end{tabular}

\section{Model Pembelajaran Integrasi Scaffolding-PBL (Scf-PBL)}

Model pembelajaran integratif dalam penelitian ini dimaksudkan memadukan beberapa model, mengelola dalam satu kesatuan untuk membentuk model baru dengan kegunaan baru (http://www.dictionary.com/browse/ integrated, 2018). Penelitian (Vogel-Walcutt et al., 2011) menemukan bahwa pengetahuan yang terintegrasi (transfer pengetahuan prosedural, deklaratif, konseptual, juga keterampilan membuat keputusan) lebih baik dalam mengendapkan pengetahuan siswa. Model integrasi dalam penilitian ini adalah integrasi scaffolding problem based learning berbasis ICT.

Untuk merencanakan pembelajaran dengan mengintegrasikan pembelajaran model ScaffoldingProblem Based Learning, berikut adalah karakteristik dan proses implementasinya.

Tabel 2. Karakteristik dan Proses implementasi Problem Based Learning 
Permasalahan harus melibatkan konflik Siswa aktif terlibat pada permasalahan sebagai kognitif siswa dan harus melengkapi pengguna dan menumbuhkan idea dan keterampilan keterampilan kerja dan pengembangan yang dibutuhkan untuk menyelesaikan masalah keterampilan siswa secara teratur

Tugas instruktur adalah memfasilitasi, Siswa harus melaksanakan penelitian atau melatih, dan atau mendukung proses penyelidikan untuk mengisi kesenjangan dan metakognitif siswa untuk berkembang mendapat pengetahuan dan keterampilan yang perlu menjadi pemecah masalah dalam memecahkan masalah

Sumber: ( Webb \& Moallem, 2016)

Dengan bimbingan fasilitator, siswa dalam kelompok kecil bekerja sama untuk menganalisis masalah, membuat formula tentang permasalahan untuk dipecahkan sendiri, dan kemudian kolaborasi dalam kelompok untuk memecahkan masalah (Webb \& Moallem, 2016).

\section{Pemanfaatan ICT dalam Pembelajaran}

E-learning merupakan sebuah media elektronik dan Teknologi Informasi dan Komunikasi (ICT), termasuk berbagai macam bentuk teknologi dalam pembelajaran (Phelan, 2015). Pembelajaran dikategorikan tradisional apabila isi pembelajaran tidak memberikan fasilitas internet (0\%), dikategorikan pembelajaran berbasis web apabila menggunakan fasilitas online dengan intensitas 0$29 \%$ untuk mensuport pembelajaran tatap muka, dikategorikan pembelajaran blended/hybrid apabila menggunakan fasilitas internet 30-79\% dengan mengurangi pembelajaran tatap muka, dan dikategorikan pembelajaran online apabila menggunakan fasilitas online dengan intensitas 80-100\% (I. E. E. Allen \& Seaman, 2014). Kesimpulannya, blended learning memanfaatkan kemampuan sumber daya berbasis Internet dan teknologi untuk transformasi pembelajaran tradisional menjadi pengalaman belajar yang fleksibel, lebih mudah diakses dan lebih responsif bagi siswa (Asunka, 2017).

ICT berupa media e-learning adalah alat teknologi untuk membantu dan memfasilitasi komunikasi, pengiriman, dan pengolahan informasi melalui sarana elektronik (Brown \& Park, 2015); (Halili \& Sulaiman, 2016). Pembelajaran jarak jauh (e-learning) dapat meningkatkan dan mengendapkan pengetahuan, serta memberikan akses secara luas untuk meningkatkan partisipasi siswa (Safford \& Stinton, 2016). Temuan Harandi (2015) menunjukkan bahwa ketika guru menerapkan e-learning, motivasi mahasiwa akan lebih baik dihasilkan. Pembelajaran jarak jauh dan terbuka (open distance learning) menjadi faktor kunci dalam memperluas akses pada pendidikan tinggi, tetapi retensi dan penyelesaian adalah rendah untuk siswa kejuruan (Safford \& Stinton, 2016). Pembelajaran jarak jauh berguna untuk mengatasi keterbatasan ruang kelas, serta hambatan jarak dan waktu dalam pelaksanaan kegiatan belajar mengajar (Suparman, 2012). Namun demikian (Gunn \& 
Pitt, 2003) menyimpulkan bahwa siswa tidak menghendaki tatap muka digantikan terlalu banyak dengan kemasan pembelajaran berbasis komputer. Ada satu jenis kegiatan pembelajaran di samping presentasi, diskusi, dan mengerjakan kuis, yaitu kegiatan e-learning seperti kegiatan chatting, forum, pengiriman file, yang perlu strategi untuk mencapai tujuan (Al-doseri, Elgazzar, \& Nouby, 2016). Desain lingkungan pembelajaran blended mengandung empat tantangan utama, yaitu 1) menggabungkan fleksibilitas, 2) merangsang interaksi, 3) memfasilitasi proses belajar siswa, dan 4) mendorong iklim belajar afektif (Boelens, De Wever, \& Voet, 2017).

Penelitian menunjukkan bahwa pencapaian prestasi antara pembelajaran tatap muka dan pembelajaran blended dengan hasil uji t muncul bahwa pada pembelajaran blended ( $\mathrm{M}=84,49$ dengan $\mathrm{SD}=10,19)$, skor tertinggi untuk pembelajaran blended dibanding pembelajaran tatap muka $(\mathrm{M}=82,13$ dengan $\mathrm{SD}=10,50, \mathrm{t} 137=1.31, \mathrm{p}=\mathrm{ns}$ dengan tidak ada perbedaan signifikansi). Maka dapat disimpulkan bahwa pembelajaran blended dapat mencapai hasil lebih baik dibandingkan pembelajaran tatap muka (Tseng, H., \& Walsh, E. J., 2016).

Dari banyak hasil penelitian di atas dapat disimpulkan bahwa pembelajaran yang baik harus melibatkan penggunaan ICT untuk memberikan fleksibilitas belajar, namun siswa juga tidak menginginkan penggantian tatap muka yang berlebihan. Dengan demikian pada pembelajaran praktek, lebih cocok menggunakan pembelajaran campuran sebagai support untuk terciptanya kompetensi siswa.

Dari review antara model pembelajaran tatap muka, pembelajaran campuran, dan pembelajaran online, model blended learning lebih mengakomodasi tujuan pembelajaran untuk pembelajaran bidang vokasional untuk mendapatkan HOTS. Blended learning tentu melibatkan fasilitas web yang tidak mudah, namun saat ini sudah banyak ahli IT yang merancang pembelajaran blended yang mudah dipakai.

Tabel 3. Dasar Pemilihan Model Pembelajaran

\begin{tabular}{|c|c|c|c|c|}
\hline No & $\begin{array}{c}\text { Hasil Penelitian } \\
\text { Ahli }\end{array}$ & $\begin{array}{c}\text { Pembelajaran Tatap } \\
\text { Muka }\end{array}$ & $\begin{array}{c}\text { Pembelajaran } \\
\text { Campuran }\end{array}$ & $\begin{array}{c}\text { Pembelajaran } \\
\text { Online }\end{array}$ \\
\hline (a) & (b) & (c) & (d) & (e) \\
\hline 1 & $\begin{array}{l}\text { (Ertmer, 1999); } \\
\text { (Sukatiman, } \\
\text { 2019) }\end{array}$ & $\begin{array}{l}\text { Apabila } \\
\text { institusi dan sarana yang } \\
\text { dimiliki mahasiswa } \\
\text { terhadap pembelajaran } \\
\text { online belum memadai }\end{array}$ & $\begin{array}{l}\text { Apabila dukungan } \\
\text { institusi dan sarana } \\
\text { yang dimiliki } \\
\text { mahasiswa } \\
\text { terhadap } \\
\text { pembelajaran } \\
\text { online memadai. }\end{array}$ & $\begin{array}{l}\text { Apabila dukungan } \\
\text { institusi dan sarana } \\
\text { yang dimiliki } \\
\text { mahasiswa } \\
\text { terhadap } \\
\text { pembelajaran } \\
\text { online memadai. }\end{array}$ \\
\hline
\end{tabular}


(Asunka, 2017); Pemanfaatan online =

(I. E. Allen et al., 0\%, memenuhi peraturan n.d.)

pembelajaran menurut DIKTI

3

(Yeung, 2015) ; Pembelajaran berpusat

(Albhnsawy \& pada guru dan siswa

Aliweh, 2016)

4

(Moreira et al., Waktu berkomunikasi

(Wannapiroon,

; dengan dosen terbatas

2014)

5

6 2014)(Albhnsawy

\& Aliweh, 2016) hanya di kelas.
(Mayer et al., Proses pembentukan 2013);(Bloom, HOTS sangat baik 1956); (Safford \&

Stinton, 2016)

$$
\text { Pemanfaatan }
$$$$
\text { online }
$$

$30 \%-79 \%$, sesuai peraturan pembelajaran DIKTI

Pembelajaran berpusat pada guru dan siswa

\section{Keterbatasan}

waktu tatap muka dengan dosen dapat diisi dengan diskusi online

Pemanfaatan online 80\%-100\%. Tidak memenuhi syarat pembelajaran tatap muka menurut DIKTI

Pembelajaran

berpusat pada siswa lebih panjang, tetapi tidak ada pembimbingan kepada siswa, dan tidak bagus untuk bidang vokasi.

Motivasi mahasiswa tinggi. mahasiswa tinggi Proses

Proses

pembentukan pembentukan HOTS cukup baik

HOTS kurang baik

\section{Sintak Model Scf-PBL berbasis ICT}

Dari hasil studi literatur yang sudah dipaparkan di atas, peneliti mengembangkan model integratif scaffolding problem based learning (PBL) dengan memanfaatkan ICT dalam mendukung motivasi mahasiswa aktif belajar (Sukatiman et al., 2020). Adapun sintak pembelajaranya adalah sebagai berikut:

a. Memberikan permasalahan nyata di lapangan.

b. Memberikan materi teori pendukung praktek dengan memperkenalkan bidang geomatika, disertai contoh-contoh dan diupload e-learning dengan aplikasi LMS yang dapat dibrowsing oleh mahasiswa melalui mobile phone.

c. Memberikan penguatan pembelajaran melalui multimedia e-learning.

d. Membimbing dan prosedural praktek dengan memanfaatkan ICT untuk memberi dasar kompetensi awal mahasiswa. 
e. Mahasiswa membangun sendiri pengetahuannya dengan bimbingan guru/instruktur dan asisten (tutee).

f. Menjelaskan sistem penilaian praktek termasuk standar kelulusan minimal 80.

g. Membagi kelas besar menjadi kelopok yang lebih kecil.

h. Mengingatkan tentang kompetensi awal yang sudah dikuasai mahasiswa (ZPD), yaitu teori menyipat datar, menentukan sudut dan jarak, dengan alat-alat berbasis optis (alat levelling, dan teodholit).

i. Permasalahan yang sudah diberikan oleh dosen/tutor kemudian harus dilihat kembali oleh mahasiswa terhadap apa yang diberikan, apa yang tidak diketahuinya, dan cara apa yang diizinkan.

j. Mahasiswa kemudian menentukan metode umum, seperti menyatakan ulang masalah sehingga masalah lebih sederhana.

k. Mahasiswa membuat perhitungan dan metode pelaksanaan yang diperlukan sesuai dengan kondisi lapangan.

1. Membandingkan hasil pengukuran mahasiswa dengan standar yang berlaku di Indonesia SNI

m. Mempresentasikan hasil praktek.

n. Medokumentasikan hasil praktek melalui laporan portofolio

\section{Penelitian Tindakan Kelas}

Penelitian tindakan didefinisikan sebagai proses mencari tahu secara terkendali yang bersiklus dan bersifat reflektif, yang mengarah untuk melakukan perbaikan sistem, metode kerja, proses, dan konten (Kemmis, S., \& McTaggart, 2005). Lebih jauh penelitian tindakan bertujuan untuk:

a. Mereorientasi kualitas isi, input, proses dan outcome pembelajaran

b. Memupuk budaya meneliti para guru agar memiliki dorongan untuk mencapai pemecahan permasalahan pembelajaran;

c. Mendorong dan meningkatkan produktifitas meneliti para guru di bidang pendidikan.

d. Menjalin kerjasama antar pendidik dalam menyelesaikan permasalahan pendidikan.

Kemmis dan McTaggart mengakui bahwa tahap-tahap yang ditentukan dalam model Action Research Spiral dapat tumpang tindih dan rencana awal yang dikembangkan untuk penelitian dapat menjadi usang dalam durasi waktu singkat karena berbagai faktor. Penelitian tindakan berguna untuk memberikan solusi penyelesaian masalah melalui tindakan nyata, bukan hanya melihat gejala tertentu kemudian menjelaskan apa yang terjadi dengan gejala tersebut (Arikunto, 2010).

Prinsip dasar penelitian tindakan meliputi penelitian berkelanjutan, integral, ilmiah, dan lingkup (Halim et al., 2014). Karakteristik penelitian tindakan mencakup beberapa hal sebagai berikut. 
a. Model pembelajaran inquiri di mana penelitian dimulai dari permasalahan nyata di kelas yang kesehariannya dihadapi oleh pendidik dan peserta didik.

b. Tujuan penelitian adalah untuk memperbaiki secara langsung

c. Bersifat reflektif secara berkelanjutan.

d. Lebih mengedepankan kolaboratif antar pendidik.

\section{METODE}

Penelitian ini menggunakan metode diskriptif kualitatif dengan partisipasi dari guru-guru SMK $\mathrm{N} 1$ Jenar yang berjumlah 20 orang yang sedang dan akan membutuhkan kenaikan jabatan fungsional. Peneliti memberikan pelatihan bagi guru-guru tersebut melalui seminar, pembimbingan, serta pengajaran PTK berkarakter abad-21. Setelah selesai pemberian teori dilanjutkan dengan pembimbingan kepada guru hingga mampu menyusun proposal penelitian tindakan kelas pada bidang materi ajar yang diampu. Pelaksanaan kegiatan pengabdian melalui PTK pada para guru di SMK N I Jenar yang berjumlah 20 orang dilakukan dengan pelatihan. Pelatihan dibagi dalam 5 tahapan, yaitu pemberian pendalaman tentang penyusunan PTK yang meliputi, 1) pemberian motivasi melalui paparan inovasi pembelajaran, 2) paparan materi, 3) pendampingan penemuan masalah kepada guru kelas, 4) konsultasi judul PTK yang inovatif dan memiliki karakter pembelajaran abad-21. Konsultasi meliputi inovasi model yang menjamin keaktifan siswa belajar, penggunaan media berbasis Learning Management System (LMS), dan penyusunan assesemen berbasis vokasional HOTS, dan 5) konsultasi lanjutan secara daring untuk memastikan proposal dapat dilaksanakan oleh guru.

\section{HASIL DAN PEMBAHASAN}

Fakta di lapangan menunjukkan banyak guru mengalami kesulitan dalam melakukan penulisan karya ilmiah khususnya penelitian tindakan kelas. Kesulitan penulisan karya ilmiah PTK meliputi bentuk, sistematika, serta secara substansial. Guru masih sulit dan terkendala karena kurangnya budaya menulis dan membaca. Hal tersebut dibuktikan dengan adanya faktor aksesibilitas terhadap jurnal, buku, dan majalah ilmiah yang menjadi penyebab wawasan penulisankarya ilmiah. Lebih lanjut tentang PTK, terdapat anggapan bahwa meneliti adlah kegiatan yang sulit serta menghabiskan banyak waktu. Guru kadang tidak ingin menulis dan melaksanakan PTK karena repot dengan kesibukkan administratif. Penelitian Tindakan Kelas (PTK) melalui pelatihan oleh pengajar-pengajar UNS dapat memotivasi sehingga menjadi bagian intervensi penting untuk mendorong guru melakukan Penelitian Tindakan Kelas (PTK). 
Pada materi pertama Inovasi pembelajaran abad-21 menjelaskan model pembelajaran inovatif abad-21 baik inovasi terhadap model, metode, media, maupun cara mengevaluasi pembelajaran di kelas, sehingga peserta pelatihan dapat memahami arti model-model pembelajaran, pentingnya model pembelajaran, dan metode pembelajaran yang inovatif abad-21 (Akbar, Panuntun and Asikin, 2021; Elisanti and Prayitno, 2018; Purwanto et al., 2019; (Elisanti et al., 2020).

Materi kedua merupakan pendalaman materi PTK yang mencakup konsep dasar, tujuan, prinsip dasar, dan karakteristik PTK. Pendalaman materi tersebut diharapkan mempu meningkatkan kemampuan guru sehingga peserta pelatihan dapat menjelaskan model Penelitian Tindakan Kelas (PTK). Penelitian tindakan yang biasa digunakan meliputi langkah-langkah dan penyusunan proposal. Pemberian materi dapat memperluas wawasan guru dalam hal pengertian proposal serta sistematika proposal PTK. Selain itu, peserta dapat mengetahui cara membuat judul PTK, membuat bidang kajian, menyusun pendahuluan, menyusun perumusan masalah, tujuan penelitian, manfaat hasil penelitian, daftar pustaka, dan rencana biaya. Materi keempat bimbingan penyusunan proposal dilaksanakan secara individu melalui curah pendapat terhadap permasalahan guru di kelas pada materi yang diampu. Dari pembimbingan secara individu peneliti akanmemahami dan memberi solusi terhadap permasalahan nyata yang dihadapi guru sehingga para peserta dapat terlatih mengaplikasikan penulisan dan penyusunan proposal PTK.

Pelatihan penelitian tindakan kelas melalui penyelenggaran seminar "UNS Mengajar Indonesia" dapat meningkatkan minat guru dalam merancang menyelesaikan permasalahan konsep materi sulit yang diajarkan kepada siswa. Guru juga bisa mengeksplorasi diri dalam penulisan karya ilmiah serta dapat meningkatkan profesionalisme (Akbar et al., 2021). Indikator awal dari keberhasilan seminar bahwa pada pelaksanaan seminar tersebut peserta tekun serta aktif dalam menemukan tema dan judul Penelitian Tindakan Kelas (PTK). Hal tersebut tergambar pada gambar 2 di bawah ini.

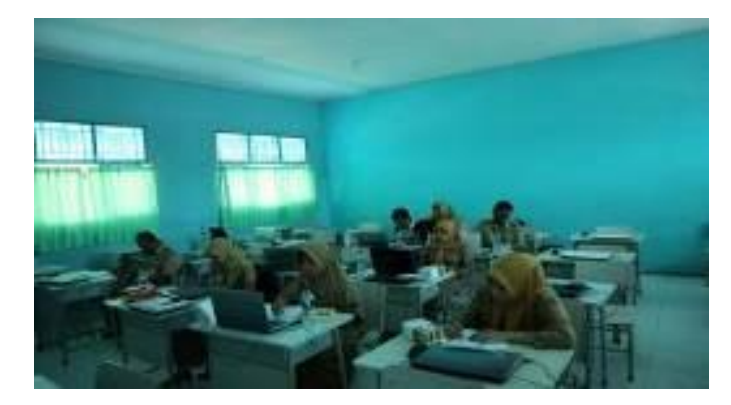

Gambar 2. Peserta dengan tekun aktif menemukan tema PTK

Gambar 2 menunjukkan bahwa peserta dengan tekun dan aktif menemukan tema penelitian tindakan kelas. Hasil pelatihan dan pendampingan PTK menunjukkan terdapat 12 guru dari 20 guru 
(60\%) mengajukan rancangan penelitian dengan judul penelitian dan hasil diskusi dengan tim yang dapat dilihat pada tabel berikut.

Tabel 4. Hasil Rancangan PTK Guru SMK N I Jenar Sragen.

Peserta Jumlah Guru yang mengajukan Judul Rancangan PTK

\begin{tabular}{llllll}
\hline & & Penggunaan & Penggunaan & Pemanfaatan & Sikap \\
& & model & Metode & Media & \\
20 & 11 & 5 & 2 & 2 & 2
\end{tabular}

Dari tabel 4 di atas menunjukkan bahwa melalui pelatihan PTK, para guru dapat memahami, menganalisis, dan mengevaluasi pembelajaran yang sudah dilakukan. Hal tersebut terlihat saat diskusi. Para guru sangat tertarik dengan situasi riil pembelajaran saat menentukan tindakan PTK, guru juga cukup kesulitan memahami serta menganalisis masalah pembelajaran, penentuan jenis tindakan komponen pembelajaran, metode pelaksanan PTK serta pelaporannya.

Dari hasil perencanaan PTK guru-guru SMK N I Jenar, peneliti melakukan kajian terhadap judul dan inovasi pembelajaran pada tabel 5 di bawah ini.

Table 5. Outcome: Pendampingan Pengajar Pada Guru-Guru SMK N I Jenar

\begin{tabular}{|l|l|l|l|l|}
\hline \multirow{2}{*}{ No } & $\begin{array}{c}\text { Nama } \\
\text { Guru } \\
\text { (Inisial) }\end{array}$ & \multicolumn{1}{|c|}{ Judul } & \multicolumn{1}{|c|}{$\begin{array}{c}\text { Saran Inovasi Pembelajaran yang } \\
\text { Direncanakan }\end{array}$} \\
\hline 1 & Budi & $\begin{array}{l}\text { Upaya Peningkatan Kualitas } \\
\text { Pembelajaran Praktek Pemeliharaan } \\
\text { Kelistrikan Kendaraan Ringan dengan } \\
\text { Metode PBL di Kelas XII Program } \\
\text { Keahlian Teknik Otomotif SMK N I } \\
\text { Jenar }\end{array}$ & $\begin{array}{l}\text { Model Problem Based Learning. } \\
\text { Saran: lakukan pembelajaran penyelesaian } \\
\text { masalah dengan mengintegrasikan mata } \\
\text { pelajaran yang sudah dikuasai oleh siswa. Guru } \\
\text { lebih berperan sebagai fasilitator serta } \\
\text { memastikan siswa melakukan kerjasama untuk } \\
\text { memecahkan masalah dengan bimbingan guru. }\end{array}$ \\
\hline 2 & Dian & $\begin{array}{l}\text { Peningkatan Hasil Belajar Kimia pada } \\
\text { Materi Pokok Senyawa Hidro Karbon } \\
\text { dengan Menggunakan Startegi } \\
\text { Pembelajaran Peta Konsep }\end{array}$ & $\begin{array}{l}\text { Model Peta Konsep banyak disukai oleh guru, } \\
\text { karena dalam menyelesaikan pembelajaran } \\
\text { semester guru menerapkan konsep yang sesuai } \\
\text { dengan sifat materi. }\end{array}$ \\
\hline 3 & $\begin{array}{l}\text { Improving Student's Writing Skills } \\
\text { Trough Video And Song }\end{array}$ & $\begin{array}{l}\text { Media ICT sangat bagus dalam mendukung } \\
\text { motivasi siswa belajar. Guru wajib mengikuti } \\
\text { perkembangan pembelajaran berbasis industri } \\
4.0 \text { dimana ICT menjadi tumpuan guru dan siswa } \\
\text { untuk melaksanakan proses belajar mengajar }\end{array}$ \\
\hline
\end{tabular}




\begin{tabular}{|c|c|c|c|}
\hline 4 & Bety & $\begin{array}{l}\text { Peningkatan Motivasi Belajar Teknik } \\
\text { Fotografi Digital Melalui Metode } \\
\text { Latihan (Drill) pada SMK Kelas XII } \\
\text { Multi Media SMK Jenar Tahun } 2020\end{array}$ & $\begin{array}{l}\text { Saran: Proses pembelajaran melalui } \\
\text { Implementasi lapangan secara nyata akan sangat } \\
\text { berguna bagi siswa. Siswa sering diajak } \\
\text { langsung terjun pada acara yang melaksanakan } \\
\text { dokumentasi baik foto maupun vidio } \\
\text { (pernikahan ,sunatan, dll). Penggunaan media } \\
\text { berbasis digital akan memberikan motivasi lebih } \\
\text { kepada siswa. }\end{array}$ \\
\hline 5 & $\begin{array}{l}\text { Enik } \\
\text { Mulati }\end{array}$ & $\begin{array}{l}\text { Meningkatkan Hasil Belajar Siswa } \\
\text { Melalui Metode Simulasi Berbantuan } \\
\text { Alat Peraga. }\end{array}$ & $\begin{array}{l}\text { Menggunakan alat peraga akan memberikan } \\
\text { pemahaman siswa lebih baik dibandingkan } \\
\text { pembelajaran abstrak (hanya teori). Menurut } \\
\text { teori pengalaman belajar kerucut Dale, Dengan } \\
\text { menggunakan alat peraga, siswa akan lebih lama } \\
\text { (70\%) mengingat apa yang dilakukan dibanding } \\
\text { pembelajaran yang hanya melalui kata-kata. }\end{array}$ \\
\hline 6 & Susilo & $\begin{array}{l}\text { Penerapan Metode Discoveri di SMK N } \\
\text { I Jenar Kab. Sragen }\end{array}$ & $\begin{array}{l}\text { Pembelajaran penemuan merupakan salah satu } \\
\text { yang direkomendasi dalam kurikulum K-13 } \\
\text { yang sedang berlaku. Lakukan inovasi tugas } \\
\text { yang menjamin siswa dapat membuktikan } \\
\text { sebuah teori (contoh: berikan simulasi dengan } \\
\text { malam untuk membuktikan benda-benda bisa } \\
\text { melayang, tenggelam, dan mengapung) }\end{array}$ \\
\hline 7 & Ratna & $\begin{array}{l}\text { Upaya Perbaikan Perilaku Siswa Nama } \\
\text { Budi (samaran) dari Kebiasaan } \\
\text { terlambat Masuk Sekolah. }\end{array}$ & $\begin{array}{l}\text { Keberhasilan pendidikan bukan hanya dari ranah } \\
\text { kognitif dan keterampilan saja, tetapi sikap } \\
\text { menjadi penting dalam capaian kompetensi. Hal } \\
\text { ini dibuktikan bahwa industri lebih } \\
\text { membutuhkan tenaga kerja yang memiliki } \\
\text { akhlak mulia yang dapat bertanggung jawab } \\
\text { terhadap pekerjaan yang diembannya. }\end{array}$ \\
\hline 6 & Heru & $\begin{array}{l}\text { Meningkatkan Hasil Belajar Siswa } \\
\text { Melalui Media Bangun Ruang dengan } \\
\text { pendekatan Visual Inquiri }\end{array}$ & $\begin{array}{l}\text { Menggunakan alat peraga akan memberikan } \\
\text { pemahaman siswa lebih baik dibandingkan } \\
\text { pembelajaran abstrak (hanya teori). Menurut } \\
\text { teori pengalaman belajar kerucut Dale, Dengan } \\
\text { menggunakan alat peraga, siswa akan lebih lama } \\
\text { (70\%) mengingat apa yang dilakukan dibanding } \\
\text { pembelajaran yang hanya melalui kata-kata }\end{array}$ \\
\hline 7 & Udi & $\begin{array}{l}\text { Meningkatkan Hasil Belajar Siswa } \\
\text { Kelas X TKR SMK N Jenar dengan } \\
\text { Menerapkan Inquiri Terbimbing }\end{array}$ & $\begin{array}{l}\text { Model inquiri sangat dianjurkan dalam } \\
\text { melaksanakan kurikulum 13, karenamenjamin } \\
\text { siswa aktif. Guru memiliki peran sebagai } \\
\text { fasilitator dan scaffolding terhadap pengetahuan }\end{array}$ \\
\hline
\end{tabular}




\begin{tabular}{|c|c|c|c|}
\hline & & & $\begin{array}{l}\text { awal siswa, dan selanjutnya siswa aktif untuk } \\
\text { mengkonstruk pengetahuannya sendiri. }\end{array}$ \\
\hline 8 & Suwardi & $\begin{array}{l}\text { Meningkatkan Kedisiplinan Siswa } \\
\text { untuk Mencegah Perilaku Membolos } \\
\text { melalui pendekatan Behavioristik } \\
\text { Siswa Kelas X Semester gasal jurusan } \\
\text { TPI }\end{array}$ & $\begin{array}{l}\text { Keberhasilan pendidikan bukan hanya dari ranah } \\
\text { kognitif dan keterampilan saja, tetapi sikap } \\
\text { menjadi penting dalam capaian kompetensi. Hal } \\
\text { ini dibuktikan bahwa industri lebih } \\
\text { membutuhkan tenaga kerja yang memiliki } \\
\text { akhlak mulia yang dapat bettanggung jawab } \\
\text { terhadap pekerjaan yang diembannya. }\end{array}$ \\
\hline 9 & Winarti & $\begin{array}{l}\text { Penerapan Metode Pembelajaran Tutor } \\
\text { Teman Sebaya untuk Meningkatkan } \\
\text { Hasil Belajar Menjahit Busana Di SMK } \\
\text { N I Jenar Kab. Sragen }\end{array}$ & $\begin{array}{l}\text { Pembelajaran Tutor sebaya, termasuk } \\
\text { pembelajaran abad-21 yang akan memunculkan } \\
\text { ciri pembelajaran } 4 \mathrm{C} \text {, yaitu meliputi komunikasi } \\
\text { antar siswa maupun siswa dengan guru, } \\
\text { kerjasama, pemikiran kritis dan pemecahan } \\
\text { masalah, dan pemikiran kreatif. Sangat sesui } \\
\text { untuk siswa Vokasi. }\end{array}$ \\
\hline 10 & Erni & $\begin{array}{l}\text { Upaya Peningkatan Keterampilan } \\
\text { Berbicara Bahasa Jawa melalui Metode } \\
\text { "Story Telling" Siswa Kelas XII TKJ } \\
\text { SMK N I Jenar Kab. Sragen tahun } 2020\end{array}$ & $\begin{array}{l}\text { Pembelajaran siswa aktif melalui kreatifitas } \\
\text { siswa bercerita, termasuk ke dalam pembelajaran } \\
\text { siswa aktif yang memberi dampak pada } \\
\text { mengendapnya ilmu pada diri siswa secara } \\
\text { permanen. Fungsi guru lebih kepada pendalaman } \\
\text { materi yang dikuasai siswa. }\end{array}$ \\
\hline 11 & Anita & $\begin{array}{l}\text { Upaya Meningkatkan Minat dan } \\
\text { Kemampuan Siswa dalam Membuat } \\
\text { Hiasan pada Busana (Embro Dony) } \\
\text { Melalui Model Pembelajaran } \\
\text { Kooperatif }\end{array}$ & $\begin{array}{l}\text { Pembelajaran Kooperatif sangat dianjurkan } \\
\text { dalam mata pelajaran praktek, dimana masing- } \\
\text { masing siswa diberikan peran aktif dalam } \\
\text { mengkonstruk suatu pengetahuan. Prinsip dalam } \\
\text { meningkatkan minant siswa milenial adalah } \\
\text { memanfaatkan ICT yang dimiliki siswa. Pada } \\
\text { siswa era millennial, gadget merupakan satu } \\
\text { benda yang semuanya memiliki. Lakukan } \\
\text { perencanaan pembelajaran kooperatif dengan } \\
\text { memberikan permasalahan yang dapat } \\
\text { diselesaiakn melalui kerja sama oleh beberapa } \\
\text { siswa. }\end{array}$ \\
\hline
\end{tabular}

Melalui pengalaman bertahun-tahun guru dalam mengajar, guru sangat mengenali persoalan pembelajaran di kelas, tetapi masih kesulitan menyajikan dalam bentuk tulisan yang sistematis dan logis. Guru perlu memiliki wawasan pengetahuan yang lebih luas tentang berbagai jenis, model, media pembelajaran inovatif abad-21, spesifikasi, dan cara penggunaan PTK (Elisanti et al., 2018). Guru perlu memahami tentang nilai pendidikan dan pembelajaran, serta mengerti dan menguasai 
kondisi peserta didik dalam proses pembelajaran. Guru-guru yang paham mengenai kondisi siswa, akan memotivasi diri dalam perbaikan kualitas pembelajaran. Dengan demikian berinisiatif melakukan penelitian khusunya penelitian tindakan kelas (Chairunnisa \& Khuluqo, 2020).

Guru memegang peran penting dalam proses penelitian dalam mencapai tujuan, yaitu dapat menganalisis materi-materi mis konsepsi (sulit) bagi siswa untuk diberikan pemecahan masalah pada saat praktek pembelajaran di kelas dan terlibat langsung secara penuh dalam perencanaan, pelaksanaan, pengamatan, dan refleksi. Revitalisasi diperlukan melalui pengembangan dan pemberdayaan budaya literasi guru, yaitu membaca dan menulis (Twiningsih \& Elisanti, 2021). Guru diberikan kebebasan berekspresi, mengaktualisasi diri, dan melakukan aktifitas akademik yang mendukung pengembangan profesionalismenya. Para Guru juga harus dapat mengeksplorasi diri, inovatif, produktif dan kolaboratif dalam penulisan dan penelitian karya ilmiah.

Peserta pelatihan diberikan materi, sesi diskusi, dan tugas menyusun proposal Penelitian Tindakan Kelas (PTK) yang sesuai dengan pembagian kelompok dan pembimbing. Pelaksanaan bimbingan dilakukan melalui tatap muka di lokasi pelatihan. Bimbingan melibatkan para pengajar Universitas Sebelas Maret (UNS) dan pada akhir kegiatan pelatihan, peserta mengumpulkan proposal PTK.

Pelatihan penelitian tindakan kelas dapat meningkatkan kemampuan kompetensi pedagogik guru dalam memecahkan permasalahan pembelajaran, melaksanakan penelitian, kepribadian, serta keprofesionalan sehingga diharapkan pembelajaran lebih inovatif dan berkualitas seiring sejalan dengan pembelajaran berdampak positif pada peningkatan hasil belajar (Dihamri et al., 2018).

Perencanaan pelatihan PTK melalui penyelenggaran seminar "UNS Mengajar” juga dapat meningkatkan minat dan profesionalisme guru, bermanfaat meningkatkan kualitas, serta profesionlisme kepala sekolah (Asvin \& Rohman, 2018). Kegiatan tersebut dilanjutkan dengan konsultasi individu secara online agar proposal yang sudah direncanakan oleh guru dapat ditindaklajuti dengan pelaksanaan penelitian di kelas. Metode ini diharapkan dapat berkelanjutan sehingga guru-guru dapat memperoleh wawasan ilmu pengetahuan penulisan karya ilmiah terfasilitasi. Guru melalui pelatihan Penelitian Tindakan Kelas (PTK) dapat mengeksplorasi diri dalam penulisan dan pembutan proposal Penelitian Tindakan Kelas (PTK) (Chairunnisa \& Khuluqo, 2020).

Technological Pedagogical Content Knowledge (TPACK) merupakan salah satu model peningkatan kompetensi guru dan pengajar sesuai dengan penguasaan kompetensi pedagogik (Koehler, Mishra, \& Cain, 2017). Technological Pedagogical Content Knowledge (TPACK) merupakan integrasi pengetahuan dan pemahaman terkait interaksi komponen antara lain konten, 
pedagogi, dan pengetahuan teknologi. Integrasi pengetahuan Technological Pedagogical Content Knowledge (TPACK) ketika guru mempunyai pemahaman dan melakukan pengajaran sebagai konstruksi pengetahuan profesional. Pengembangan TPACK profesional yang berpusat pada pengalaman guru dengan mendefinisikan, merancang, dan pengembangan pendidikan untuk memecahkan tantangan belajar tertentu khususnya pembelajaran abad-21. Kerangka Technological Pedagogical Content Knowledge (TPACK) berusaha membantu pengembangan, penemuan teknik yang lebih baik, dan pengetahuan profesional terkait teknologi yang diimplemtasikan dan diterapkan dalam praktik pembelajaran yang berkualitas.

\section{KESIMPULAN}

Kesimpulan menunjukkan bahwa perencanaan Pelatihan Penelitian Tindakan Kelas (PTK) Melalui Penyelenggaraan Seminar UNS Mengajar dapat meningkatkan minat dan profesionalisme. Guru memiliki kemampuan untuk merancang perbaikan pembelajaran kelas pada materi yang diampunya. Program pelatihan Penelitian Tindakan Kelas (PTK) bagi guru ini telah berhasil meningkatkan kompetensi guru dalam menyusun proposal PTK. Pelatihan penelitian tindakan kelas dapat meningkatkan kemampuan kompetensi pedagogik guru dalam memecahkan permasalahan pembelajaran, melaksanakan penelitian, meningkatkan kepribadian, serta keprofesionalan, sehingga diharapkan pembelajaran lebih inovatif dan berkualitas seiring sejalan dengan peningkatan hasil belajar. Guru-guru melalui pelatihan Penelitian Tindakan Kelas (PTK) dapat melatih dan mengeksplorasi diri dalam perencanaan penulisan dan pembuatan proposal Penelitian Tindakan Kelas (PTK). Kesan dari peserta menyatakan bahwa pelatihan tersebut sangat membantu guru dalam meningkatkan pembelajaran dan sebagian besar peserta menyatakan puas. Saran peserta supaya kegiatan pelatihan dam bimbingan waktunya ditambah, agar kompetensi pedagogik guru-guru dalam pelatihan karya tulis ilmiah lebih baik.

\section{DAFTAR PUSTAKA}

Akbar, S., Panuntun, A., \& Asikin, M. (2021). Kemapuan Berpikir Kreatif Ditinjau Dari Self Regulated Learning dengan Pendekatan Open-Ended Pada Model Pembelajaran Creative Problem Solving. Qalamuna - Jurnal Pendidikan, Sosial, Dan Agama, 13(1), 11-22. https://doi.org/10.37680/qalamuna.v13i1.847

Albhnsawy, A. A., \& Aliweh, A. M. (2016). Enhancing Student Teachers' Teaching Skills Through a Blended Learning Approach. International Journal of Higher Education, 5(3), 131-136. https://doi.org/10.5430/ijhe.v5n3p131 
Allen, I. E. E., \& Seaman, J. (2014). Tracking Online Education in the United States.

Allen, I. E., Survey, B., Seaman, J., \& Survey, B. (n.d.). Tracking Online Education in the United States.

Asunka, S. (2017). “We Had a Blast!” International Journal of Mobile and Blended Learning, 9(3), 37-53. https://doi.org/10.4018/IJMBL.2017070104

Asvin, M., \& Rohman, A. (2018). Kompetensi Pengawas PAI dan Efektivitas Kepemimpinan Kepala Madrasah dalam Mengembangkan Profesionalisme Guru Madrasah Tsanawiyah di Kabupaten Ponorogo. Qalamuna - Jurnal Pendidikan, Sosial, Dan Agama, 10(2), 69-89.

Bloom, B. (1956). of Educational Goals. 18.

Budiwan, J. (2018). Pendidikan Orang Dewasa. Qalamuna - Jurnal Pendidikan, Sosial, Dan Agama, 10(2), 107-135. https://doi.org/10.31227/osf.io/b6hsq

Chairunnisa, C., \& Khuluqo, I. El. (2020). PEMBERDAYAAN GURU MELALUI PELATIHAN PENELITIAN TINDAKAN KELAS. Jurnal PKM: Pengabdian Kepada Masyarakat, 03(01), $22-30$.

Dihamri, Haimah, \& Srifitriani, A. (2018). Pelatihan penelitian tindakan kelas (PTK) bagi guru sd negeri di kecamatan sukaraja kabupaten seluma. JURNAL PENGABDIAN MASYARAKAT BORNEO, 2(1), 60-66.

Elisanti, E., \& Prayitno, B. A. (2018). The Profile of Critical Thinking Skill Students in XI Grade of Senior High School. Journal of Advances in Social Science, Education and Humanities Research,Atlantis Press, 218(ICoMSE 2017), 205-209.

Elisanti, E., Rudibyani, R. B., Prayitno, B. A., Perdana, R., \& Wulandari, K. F. N. (2020). Analysis of Students Inquiry Skills in Senior High School Though Learning Based on the Hierarchy of Inquiry Model. Journal of Advances in Social Science, Education and Humanities Research,Atlantis Press, 422(Icope 2019), 409-414.

Elisanti, E., Sajidan, S., \& Prayitno, B. A. (2018). THE EFFECTIVENESS OF INQUIRY LESSONBASED IMMUNITY SYSTEM MODULE TO EMPOWER THE STUDENTS' CRITICAL THINKING SKILL. Journal of Edusains, 10(1), 97-112.

Ertmer, P. A. (1999). Addressing first and second order barriers to change: Strategies for technology integration. Educational Technology Research and Development, 47(4), 47-61.

Gunn, A., \& Pitt, S. J. (2003). The effectiveness of computer-based teaching packages in supporting 
student learning of parasitology. Bioscience Education, 1(1), 1-14. https://doi.org/10.3108/beej.2003.01010007

Halim, L., Yong, T. K., \& Meerah, T. S. M. (2014). Overcoming Students’ Misconceptions on Forces in Equilibrium: An Action Research Study. Creative Education, 05(11), 1032-1042. https://doi.org/10.4236/ce.2014.511117

Hung, D., \& Nichani, M. (2001). Constructivism and e-Learning: Balancing Between the Individual and Social Levels of Cognition. Educational Technology, 41(2), 40-44.

Jeffrey, L. M., Milne, J., Suddaby, G., \& Higgins, A. (2014). Blended Learning: How Teachers Balance the Blend of Online and Classroom Components. Journal of Information Technology Education, 13, 121-140. https://doi.org/10.28945/1968

Kemmis, S., \& McTaggart, R. (2005). Participatory action research: Communicative action and the public sphere. In In The Sage handbook of qualitative research, 3rd edition (3rd/23 (pp. 559604).

Koehler, M. J., Mishra, P., \& Cain, W. (2017). What is Technological Pedagogical Content Knowledge (TPACK)? Journal of Education, 193(3), 60-70. https://doi.org/10.1177/002205741319300303

Mayer, A.-K., Leichner, N., Peter, J., Guenther, A., \& Krampen, G. (2013). Developing a Blended Learning Approach to Foster Information Literacy in German Psychology Education. Procedia - Social and Behavioral Sciences, 93, 1259-1262. https://doi.org/10.1016/j.sbspro.2013.10.025

McLeod, S., \& Richardson, J. W. (2014). School administrators and K-12 online and blended learning. In Handbook of Research on K-12 Online and Blended Learning. https://doi.org/10.1017/CBO9781107415324.004

Mok, J. (1993). the Use of Language To Enhance Thinking in Problem-Based Learning Tutorial Groups. 1989, 191-207.

Moreira, F., Ferreira, M. J., Santos, C. P., \& Durão, N. (2017). Evolution and use of mobile devices in higher education: A case study in Portuguese Higher Education Institutions between 2009/2010 and 2014/2015. Telematics and Informatics, 34(6), 838-852. https://doi.org/10.1016/j.tele.2016.08.010

Polya, G. (1957). Polya's Problem Solving Techniques. In How To Solve It (Issue 2, pp. 1-4).

Purwanto, Y. P., Masykuri, M., Soeparmi, S., \& Elisanti, E. (2019). Analysis of Science Students Critical Thinking Skill in Junior High School Analysis of Science Students Critical Thinking 
Skill in Junior High School. Journal of Physics: Conference Series, 1233(012086), 1-9. https://doi.org/10.1088/1742-6596/1233/1/012086

Safford, K., \& Stinton, J. (2016). Barriers to blended digital distance vocational learning for nontraditional students. British Journal of Educational Technology, 47(1), 135-150. https://doi.org/10.1111/bjet.12222

Stein, B. and. (1984). The ideal problem solver: A guide for improving thinking, learning, and creativity. New York, NY : W.H. Freeman, c1984.

Sukatiman. (2019). Framework of the Blended Learning in Vocational Study to Achieve Hot Skills. 317(IConProCS), 239-244.

Sukatiman, S., Akhyar, M., Siswandari, \& Roemintoyo. (2020). Enhancing higher-order thinking skills in vocational education through scaffolding-problem based learning. Open Engineering, 10(1), 612-619. https://doi.org/10.1515/eng-2020-0070

Twiningsih, A., \& Elisanti, E. (2021). Development of STEAM Media to Improve Critical Thinking Skills and Science Literacy: A Research and Development Study in SD Negeri Laweyan Surakarta , Indonesia. International Journal of Emerging Issues in Early Childhood Education (IJEIECE), 3(1), 25-34.

Vogel-Walcutt, J. J., Gebrim, J. B., Bowers, C., Carper, T. M., \& Nicholson, D. (2011). Cognitive load theory vs. constructivist approaches: Which best leads to efficient, deep learning? Journal of Computer Assisted Learning, 27(2), 133-145. https://doi.org/10.1111/j.13652729.2010.00381.x

Wannapiroon, P. (2014). Development of Research-based Blended Learning Model to Enhance Graduate Students' Research Competency and Critical Thinking Skills. Procedia - Social and Behavioral Sciences, 136, 486-490. https://doi.org/10.1016/j.sbspro.2014.05.361

Wellesley R. Foshay ., C. (2009). Some Principles Underlying the Cognitive Approach to Instructional Design†. 1-3.

Yeung, S. yin S. (2015). Conception of teaching higher order thinking: perspectives of Chinese teachers in Hong Kong. Curriculum Journal, 26(4), 553-578. https://doi.org/10.1080/09585176.2015.1053818. 
MENINGKATKAN MINAT GURU PADA PERENCANAAN PENELITIAN TINDAKAN KELAS...

Waluyo, Sukatiman 